\title{
Production and fate of dimethylsulfide and dimethylsulfoniopropionate in pelagic mesocosms: the role of sedimentation
}

\author{
Ronald Osinga ${ }^{1}$, Rik L. J. Kwint ${ }^{2}$, Wilma E. Lewis ${ }^{1}$, Gijsbert W. Kraay ${ }^{1}$, \\ Jan Dirk Lont ${ }^{1}$, Han J. Lindeboom ${ }^{1}$, Fleur C. van Duyl ${ }^{1, *}$ \\ ${ }^{1}$ Netherlands Institute for Sea Research, PO Box 59, 1790 AB Den Burg, Texel, The Netherlands \\ ${ }^{2}$ Laboratory for Applied Marine Research-TNO, PO Box 5, 1780 AB Den Helder, The Netherlands
}

\begin{abstract}
Elevated concentrations of dimethylsulfide (DMS) sometimes occur in sea water during phytoplankton blooms. To determine the factors controlling the concentration of DMS in sea water, the development and fate of a bloom dominated by Phaeocystis sp. was studied in relation to the production and fate of DMS and its precursor $\beta$-dimethylsulfoniopropionate (DMSP) in a pelagic mesocosm experiment. The part of this study described here focused on the role of sedimentation of algae as a loss factor for DMSP and as a trigger mechanism for DMS production. A hypothesis tested was that high DMS concentrations occur after a mass release of DMSP from algae due to mass sedimentation followed by cell lysis on the mesocosm floor. This was studied by monitoring Phaeocystis cell numbers, chlorophyll a, particulate DMSP, dissolved DMSP and DMS in the water column, and by daily measurements of the sedimentation of Phaeocystis cells. We evaluated a technque for measuring DMSP indirectly as acrylate by high-performance liquid chromatography (HPLC). This method seemed to be hampered by DMSP-lyase activity of Phaeocystis sp. during sample processing, but gave good results when Phaeocystis was not dominant. Sedimentation rates of Phaeocystis sp. were found to be high and constantly related to the standing stock in the water column. The average sinking velocity of Phaeocystis cells was $1.4 \mathrm{~m} \mathrm{~d}^{-1}$ At the decline of the bloom, sedimentation accounted for approximately $50 \%$ of the observed loss of Phaeocystis biomass, which indicates that cell lysis may have been important as well at this time. The decline of the bloom did not result in an elevated DMS concentration. However, a significant peak in DMS was observed at the end of the exponential growth phase of the Phaeocystis bloom. It was concluded that the decline of a Phaeocystis bloom does not lead to an elevated DMS concentration in the water column. The continuously high sedimentation of living Phaeocystis cells suggests that, in these mesocosms, lysis after sedimentation was an important mechanism for release of DMSP from cells and, hence, production of DMS. Nevertheless, this mechanism in itself can not explain the strong fluctuations in the DMS concentration observed in this experiment.
\end{abstract}

KEY WORDS: Phaeocystis - Sedimentation DMS D DMSP

\section{INTRODUCTION}

Dimethylsulfide (DMS) has gained increasing scientific interest due to its proposed role as an 'anti-greenhouse' gas (Charlson et al. 1987. Andreae 1990, Lawrence 1993). Most atmospheric DMS is emitted from oceans and seas (Andreae 1990), where it is formed

•E-mail: duyl@nız.nl mainly from (bio)chemical conversion of $\beta$-dimethylsulfoniopropionate (DMSP), a compound that is produced by several marine phytoplankton species (Keller et al. 1989).

No clear relationship exists between phytoplankton biomass and DMS concentrations in sea water (Holligan et al. 1987, Turner et al. 1988, Iverson et al. 1989). This may be caused by fluctuations in the production and fate of both DMSP and DMS. Interspecific variation in DMSP production by algae, fluctuations in the 
intracellular DMSP concentration in algal cells, grazing of algae by zooplankton, demethylation of DMSP to 3-mercaptopropionate, bacterial consumption of DMS, and photochemical oxidation of DMS to dimethylsulfoxide (DMSO) have all been reported to affect marine DMS concentrations (Brimblecombe \& Shooter 1986, Dacey \& Wakeham 1986, Kiene \& Taylor 1988. Keller et al. 1989, Kiene \& Bates 1990, Matrai \& Keller 1994). In order to gain insight into the complex relationship between phytoplankton biomass and DMS, a pelagic mesocosm experiment was performed, in which the development and fate of an algal bloom was studied in relation to the production and fate of DMS and DMSP.

The study described here focuses on sedimentation, a process that has hardly been studied in relation to DMSP and DMS. Sedimentation of algae and other particles containing DMSP, like faecal pellets from zooplankton, will have 2 effects: it will decrease the concentration of DMSP in sea water, as was indicated by Belviso et al (1993), and it will supply the benthic system with DMSP, leading to benthic DMS production (Nedwell et al. 1994). Hence, elevated DMS concentrations may occur after mass sedimentation of algae. Mass sedimentation at the end of a bloom has been described for diatoms (Riebesell 1989, Olesen 1993). Kwint et al. (1993) observed peaks in DMS formation after the decline of a diatom bloom in a mesocosm experiment.

Diatoms, however, are not regarded as important DMSP producers (Keller et al. 1989). Hence, our experiments focused on the Prymnesiophyte Phaeocystis sp. which is an important DMSP producer (Keller et al 1989), with a world-wide distribution (Baumann et al. 1994). Elevated concentrations of DMS were reported during blooms of Phaeocystis sp. (Barnard et al. 1984, Holligan et al. 1987, Gibson et al. 1990, Liss et al. 1994), but the relation between Phaeocystis sp. and DMS formation is still unclear. Liss et al. (1994) suggested that a mass release of DMSP may occur at the decline of a bloom, leading to the observed elevated DMS concentrations.

We tested the hypothesis that these elevated DMS concentrations are caused by a mechanism of sedimentation of Phaeocystis sp. at the end of a bloom, followed by a rapid benthic conversion of DMSP into DMS. Van Duyl et al. (1992) and Osinga et al. (1995) found that, in experimental benthic systems, bacteria responded rapidly to addition of fresh algal material dominated by Phaeocystis sp. In addition, Stefels \& Van Boekel (1993) recently discovered a strong DMSPlyase like enzyme activity in axenic cultures of Phaeocystis sp., leading to DMS production by the algae. These findings support the idea of rapid benthic conversion of DMSP into DMS: if the algae break down on the bottom, DMSP will be liberated in an environment with both high bacterial numbers and high algal lyase concentrations, resulting in a high DMS production.

There are, however, uncertainties about the fate of Phaeocystis cells at the decline of a bloom. Mass sedimentation of $P$. pouchetii was reported by Wassmann et al. (1990). In the German Bight area, Riebesell (1993) also found that sedimentation was the main loss factor for Phaeocystis sp. biomass from the upper layer. On the other hand, Van Boekel et al. (1992) found that cell lysis in the water column was the main fate of the Phaeocystis sp. spring bloom in the Dutch Coastal Zone. In this paper, we therefore not only estimated the importance of sedimentation in the production and fate of DMS and DMSP, but also studied the role of sedimentation in the development and fate of a Phaeocystis bloom.

In another study, carried out simultaneously in these mesocosms, other parameters and processes involved in the biochemical cycling of DMS and DMSP, like zooplankton abundance and bacterial DMS consumption, were monitored. The results of these measurements will be described elsewhere (Quist et al. in press)

\section{MATERIAL AND METHODS}

Mesocosms. Four 1380 l plastic bags (polyethene/ polyamide 2-layered foil) were filled with sea water collected on 14 April 1993 in the Marsdiep. The Netherlands (Dutch Coastal Zone, $52^{\circ} 59^{\prime} \mathrm{N}, 4^{\circ} 50^{\prime} \mathrm{E}$ ). At the start of the experiment, extra nutrients were added $\left(6 \mu \mathrm{mol} \mathrm{l} \mathrm{l}^{-1} \mathrm{PO}_{4}{ }^{3-}\right.$ and $\left.40 \mu \mathrm{mol} \mathrm{l^{-1 }} \mathrm{NO}_{3}{ }^{-}\right)$to create the favourable growth conditions for Phaeocystis sp The open bags (Fig. 1) were placed outdoors in a sheltered part of the harbour of Den Helder (located next to the Marsdiep area). The experiment was run between 16 April and 21 May 1993 at field temperature. For a more detailed description of the mesocosms, see Kwint \& Kramer (1995).

Sediment traps and sampling. In 2 mesocosms, a device was placed with duplicate sediment traps at water depths of 0.5 and $2 \mathrm{~m}$ (Fig 1). The total depth of the mesocosms was $3 \mathrm{~m}$. The traps, perspex cylindrical cores (diameter $7.4 \mathrm{~cm}$, height $20 \mathrm{~cm}$ ), were emptied daily. In parallel, samples were taken from the water. column at depths of 0.5 and $2 \mathrm{~m}$, using $1.0 \mathrm{l}$ plastic bottles which were imbedded in a frame with lead. The frame with the empty bottles was let down into the mesocosm, and the stoppers were removed from the bottles underwater at the desired depth. This sampling started $3 \mathrm{~d}$ after the start of the experiment.

Water samples representing the whole depth transect were taken daily as well from these mesocosms using a peristaltic pump and a sampling tube that 


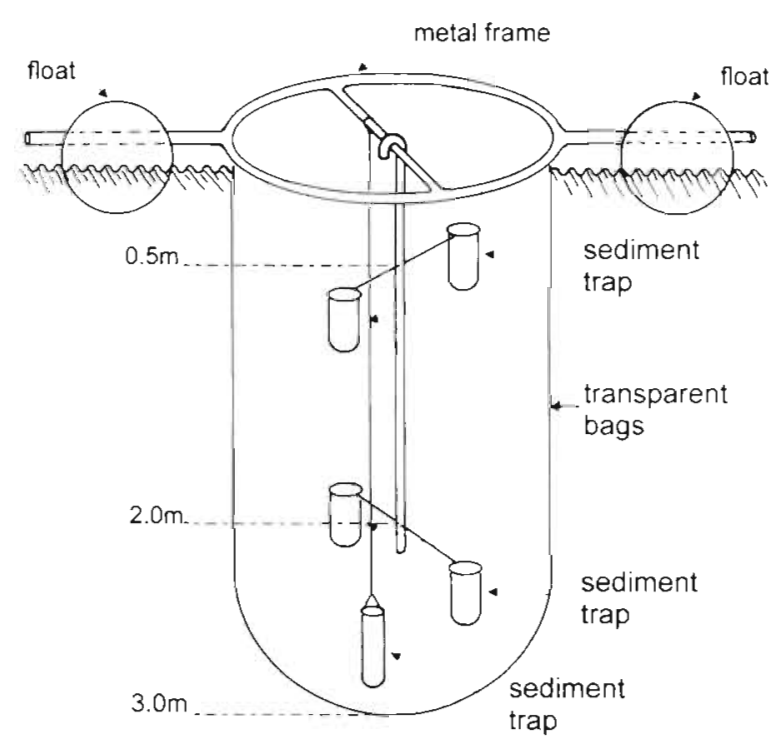

Fig. 1. Mesocosm with sediment traps. Four perspex cylindrical traps were placed in a plastic frame, which could be removed easily from the mesocosms. A further 4 smaller traps (only 1 shown) were fastened with ropes to the mesocosm frame

was randomly moved up and down through the water column.

In both mesocosms, 4 smaller sediment traps (perspex cylindrical cores, diameter $5.4 \mathrm{~cm}$, height ca $35 \mathrm{~cm}$ ) were placed in the centre of the bags near the mesocosm floor (Fig. 1). These traps were removed 14, 21, 25 and 35 d respectively after the start of the experiment. After removal, the overlying water in the trap was carefully siphoned off, and the volume of the deposited material was determined. On the first day of the experiment, a similar sediment trap was placed outside the mesocosms in the Den Helder harbour at a depth of $3 \mathrm{~m}$. This trap was also removed after $35 \mathrm{~d}$, for comparison of the mesocosm systems with the surrounding water.

All samples were transported immediately to the laboratory for further treatment.

Analytical procedures. All samples taken at 0.5 and $2.0 \mathrm{~m}$ (water column and sediment traps) were analysed for chlorophyll a and Phaeocystis cell numbers. Chlorophyll a subsamples (subsample volumes ranging between 200 and $500 \mathrm{ml}$ for the water column, and between 30 and $100 \mathrm{ml}$ for the sediment traps, depending on the expected concentration) were collected on glass fibre filters (Whatman GF/F) and measured spectrophotometrically according to Parsons et al. (1984) after extraction with $90 \%$ acetone.

For determining Phaeocystis cell numbers, $100 \mathrm{ml}$ subsamples were fixed immediately with Lugol solution ( $1 \%$ final concentration) and stored at $2^{\circ} \mathrm{C}$. Cell numbers were counted microscopically. Only living cells were counted. Colourless cells that did not reflect light any more were considered as dead.

The samples taken with the peristaltic pump were used for the determination of the average nutrient concentrations and the average DMS concentration in the water column. Nutrients (nitrate, nitrite, ammonium and phosphate) were measured according to Parsons et al. (1984) on a Technicon auto-analyzer. DMS was measured by gas chromatography (GC) according to Lindquist (1989), following the preconcentration step described by Kwint \& Kramer (1995)

The content of the small sediment traps was analysed for chlorophyll a, organic carbon and organic nitrogen. It was very diffcult to identify the Phaeocystis cells in this material. Hence, accurate determination of the cell numbers in this material was not possible. For the determination of organic carbon and nitrogen, subsamples of 3 to $10 \mathrm{ml}$ were oven-dried for $24 \mathrm{~h}$ at $60^{\circ} \mathrm{C}$. The dried samples were analysed on a Carlo Erba NA. 1500-2 elemental analyser after acidification with $6 \%$ sulfurous acid (Verardo et al. 1990).

High-performance liquid chromatography (HPLC) analysis of acrylate. Under alkaline conditions ( $\mathrm{pH} 10)$, chemical cleavage of DMSP occurs, which yields DMS and acrylate in an equimolar ratio (Dacey \& Blough 1987) This process is used for indirect measurements of DMSP concentrations: $\mathrm{NaOH}$ is added to a sample to induce chemical conversion. Subsequently, the DMS produced by this reaction is measured by GC. We will here evaluate a HPLC technique for measuring DMSP indirectly as acrylate.

Samples for the HPLC analysis were filtered under slight vacuum pressure over glass fibre filters (Whatman GF/F, diameter $47 \mathrm{~mm}$ ) to separate the dissolved from the particulate fraction. Vacuum pressure never exceeded $10 \mathrm{~cm} \mathrm{Hg}$ in order to minimize cell disruption. Biological conversion of DMSP to acrylate and DMS may occur in the samples during processing and storage, a process that will lead to an underestimation of the actual DMSP concentration in a sample. Stefels \& Van Boekel (1993) showed that the algal lyase activity of Phaeocystis sp. could be efficiently inhibited by heat. Hence, the filters were incubated for $15 \mathrm{~min}$ at $60^{\circ} \mathrm{C}$ immediately after filtration to denature the enzymes responsible for the cleavage reaction. After the incubation, the samples were stored at $-30^{\circ} \mathrm{C}$ until further processing.

Two samples of $1.9 \mathrm{ml}$ were taken from the filtrate for measurement of dissolved acrylate and DMSP. These samples were not heated, since most of the enzyme-activity was assumed to be particle-bound: Stefels \& Van Boekel (1993) found very little lyase activity in GF/F filtered samples of an axenic Phaeocystis sp. culture. One of the $1.9 \mathrm{ml}$ samples was incubated with $100 \mu 10 \mathrm{M} \mathrm{NaOH}(0.5 \mathrm{M}$ final con- 
centration) for at least $15 \mathrm{~min}$ at room temperature for chemical conversion of DMSP to acrylate and DMS. After the incubation, $100 \mu 10 \mathrm{M} \mathrm{HCl}$ was added to neutralize the $\mathrm{pH}$ in the sample. Both samples were stored at $-30^{\circ} \mathrm{C}$ in plexiglass tubes (Sartedt) until analysis.

The filters were put into a homogenisation flask together with $4.4 \mathrm{ml}$ distilled water and glass beads (diameter 0.45 to $0.5 \mathrm{~mm}$ ) and were homogenized for $30 \mathrm{~s}$ in a $\mathrm{CO}_{2}$-cooled Braun 853038 cell homogeniser. The water content of a wet $47 \mathrm{~mm}$ GF/F filter is estimated as $0.6 \mathrm{ml}$, so that the addition of $4.4 \mathrm{ml}$ distilled water results in a total volume of $5 \mathrm{ml}$ containing all particulate DMSP/acrylate from the original sample. This preconcentration step has to be accounted for when calculating the original concentration in the sample. Distilled water was used instead of filtered sea water to minimize peaks in the chromatogram that are caused by sea salt. These peaks may otherwise interfere with the acrylate peaks.

The homogenized suspension was filtered through a Whatman GF/F glass fibre filter. A $1.9 \mathrm{ml}$ subsample of the filtrate was treated with $\mathrm{NaOH}$ as described previously and stored at $-30^{\circ} \mathrm{C}$ until analysis. The remainder of the filtrate was stored at $-30^{\circ} \mathrm{C}$ without further treatment.

Analysis of these samples was performed on a Waters 600 E HPLC system, using a Waters 994 photodiode array detector, a Rosil C18 $5 \mu \mathrm{HL}$ (high loaded) column (150 by $4.7 \mathrm{~mm})$, and $25 \%(\mathrm{v} / \mathrm{v})$ methanol in distilled water as the carrier fluid. This photo-absorption detection method detects the acrylate as acrylic acid. To prevent dissociation of the acrylic acid, the carrier fluid was acidified with phosphorous acid to a $\mathrm{pH}$ of 2 . The flow rate of the carrier fluid was $1.0 \mathrm{ml} \mathrm{min}^{-1}$.

A sample volume of $100 \mu$ l was injected into the HPLC with a Hamilton syringe. To prevent pollution of the column, all samples were filtered through a $0.2 \mu \mathrm{m}$ cellulose acetate filter just before injection into the HPLC.

The system was calibrated with standard acrylic acid (Aldrich Chemicals) diluted in $10 \% \quad 0.2 \mu \mathrm{m}$ filtered aged sea water in distilled water. The aged sea water was added to the standard to create a medium with a similar sea water content as the particle-bound acrylate/DMSP samples, in which $4.4 \mathrm{ml}$ distilled water was added to $0.6 \mathrm{ml}$ sea water. A broad spectrum measurement was performed on 1 of the calibration samples to assess the optimal detection wavelength. All other samples were analyzed at a detection wavelength of $205 \mathrm{~nm}$.

DMSP concentrations were calculated by subtracting the measured acrylic acid concentrations in the untreated samples from the concentrations in the samples treated with $\mathrm{NaOH}$
The HPLC analysis of acrylate was only performed on samples from $2 \mathrm{~m}$ water depth. The volume of the subsamples used for filtration depended on the expected concentration, and were generally equal to the volumes filtered for chlorophyll a analysis.

Particulate DMSP in the water column was also measured by GC as DMS after chemical conversion with $\mathrm{NaOH}$, and these results were used to calibrate the HPLC measurements. The GC-DMSP measurements were performed following the procedures described by Stefels \& Van Boekel (1993).

Calculations. The amount $X$ of a compound ' $X$ ' collected in the sediment traps after a period $t$ is a function of the sinking velocity $V_{\mathrm{s}}$ of ' $\mathrm{X}$ ', the horizontal surface of the trap entrance $A$ and the average concentration $C_{\mathrm{d} v g}$ of ' $\mathrm{X}$ ' in the water column directly over the trap:

$$
X(t)=v_{\mathrm{s}} \times t \times C_{\mathrm{avg}} \times A
$$

Hence, the sinking velocity of ' $\mathrm{X}$ ' can be calculated as follows:

$$
v_{\mathrm{s}}=X(t) /\left(t \times C_{\mathrm{avg}} \times A\right)
$$

For each day, the sinking velocity of Phaeocystis cells was thus calculated from the results of the microscopic counts. $C_{\text {avg }}$ was calculated as the average of the cell numbers measured in the water column on 2 successive days.

There was no tidal mixing inside the mesocosms. Due to the sheltered location, there was also little wave-interaction. It was therefore assumed that resuspension of deposited material hardly occurred in these mesocosms. This allows the following simple calculation of sedimentation rates:

$$
S(X)=X / A
$$

where $S(X)=$ the sedimentation of compound ' $X{ }^{\prime} \mathrm{m}^{-2}$; $X=$ the amount of compound ' $X$ ' in the trap; $A=$ the horizontal surface area of the sediment trap entrance.

For calculation of daily sedimentation rates, a modification of Eq. (3) is used:

$$
S_{\mathrm{d}}(X)=[X(i)-X(i-1)] / A
$$

where $S_{d}(X)=$ the sedimentation of compound ' $X$ ' $\mathrm{m}^{-2}$ $\mathrm{d}^{-1} ; X(i)=$ the amount of compound ' $\mathrm{X}$ ' in the trap on Day ' $i$ ' $X(i-1)=$ the amount of compound ' $X$ ' in the trap when it was installed on Day ' $i-1$ '. This amount was calculated as the concentration in the water column on Day ' $i-1$ ' times the volume of the sediment trap. Missing values for the concentration in the water column were interpolated.

Addition of the values for daily sedimentation shows the total amount of compound ' $\mathrm{X}$ ' on the mesocosm floor after a period Ionger than $1 \mathrm{~d}$. However, decomposition of deposited material may occur during the experiment, decreasing the amount of material on the mesocosm floor The data from the small traps at the 
mesocosm floor, which were not emptied daily, gave an indication of the decomposition rate when they were compared to the cumulative daily sedimentation.

When $S_{\mathrm{d}}(X)$ has been determined, the daily net production ' $P_{\mathrm{n}}$ ' of compound ' $\mathrm{X}$ ' in the water column can be calculated as follows:

$$
P_{\mathrm{n}}=C(i)-C(i-1)+\left[S_{\mathrm{d}}(X) \times V\right]
$$

where $C(i)=$ the concentration of compound ' $X$ ' in the water column on Day ' $i$ '; $C(i-1)=$ the concentration of compound ' $\mathrm{X}$ ' in the water column on Day ' $\mathrm{i}-1$ '; $V=$ the volume of the water column over $1 \mathrm{~m}^{2}$

\section{RESULTS}

In the water column of these mesocosms, no abvious differences were observed between the Phaeocystis cell numbers at 0.5 and at $2.0 \mathrm{~m}$. The log of the ratio of the total amount of Phaeocystis cells counted over the whole $35 \mathrm{~d}$ period at $0.5 \mathrm{~m}$ and the total cell numbers counted at $2.0 \mathrm{~m}$ did not differ significantly from 0 (paired $t$-test, 2 pairs, $\alpha=0.05$ ). Therefore, cell numbers in the water column are presented as the averages of the 2 depths (Fig 2).
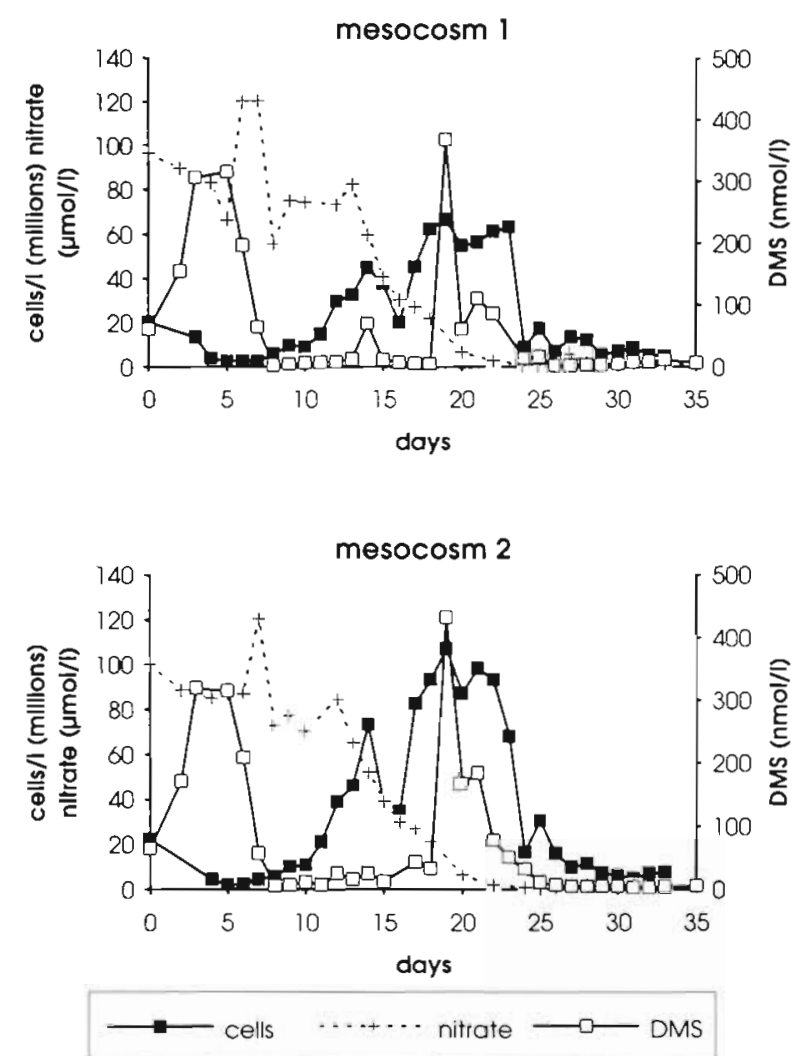

Fig. 2. Development of the Phaeocystis bloom and the concentrations of nitrate and DMS in the mesocosms
Although the cell numbers in Mesocosm 1 were in general lower than in Mesocosm 2 (Fig. 2), the patterns are rather similar in both cases. A drop in cell numbers was observed a few days after the experiment started. After $10 \mathrm{~d}$, Phaeocystis sp. started blooming, reaching the highest cell numbers between Days 17 and 23, when values up to 70 million cells $1^{-1}$ (Mesocosm 1) and 115 million cells $1^{-1}$ (Mesocosm 2) were found. The bloom declined at Day 24. Thereafter, cell numbers remained low until the end of the experiment. The cell counts did not distinguish between colonial and non-colonial cells. It was however observed that colonies were abundant throughout the blooming period.

Fig. 2 also shows the concentration of nitrate in the water column. This concentration shows a strong decrease during the blooming period of Phaeocystis sp., with the lowest levels occurring at and after the decline of the bloom.

The measured DMS concentrations are shown in Fig. 2 as well. Phaeocystis cell numbers showed no correlation with DMS. High DMS concentrations were found between Days 2 and 7 , and a peak was observed on Day 19. After Day 19, the DMS concentration remained elevated for a few days before it dropped to background levels. This pattern was strikingly similar in both mesocosms.

The chlorophyll a concentration in the water column (data not shown) did not follow exactly the same pattern as Phaeocystis sp. In Fig. 3, the ratio between Phaeocystis cells numbers and the measured chlorophyll a concentrations in the water column is plotted versus time. The ratio was highest in the periods before and after the bloom of Phaeocystis sp. When Phaeocystis cell numbers were highest, the ratio dropped to values around $0.2 \mathrm{pg} \mathrm{cell}^{-1}$. After the bloom, the ratio in Mesocosm 1 was considerably higher than the ratio in Mesocosm 2.

Phaeocystis cell numbers in the sediment traps in both mesocosms at 0.5 and $2.0 \mathrm{~m}$ are presented in

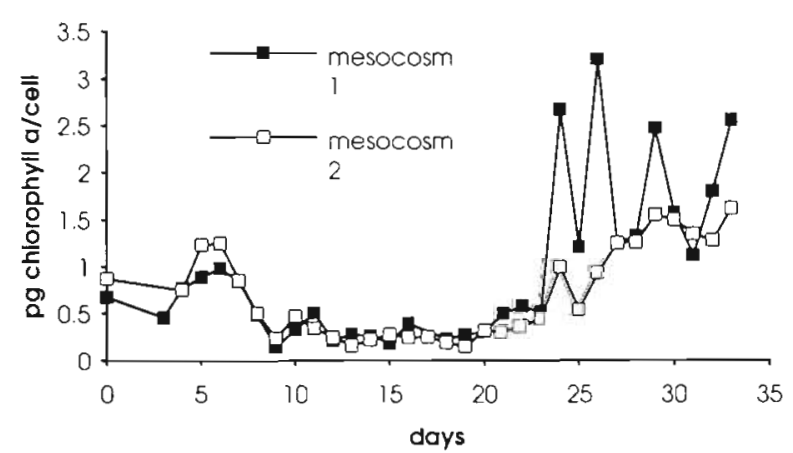

Fig. 3. Ratio between Phaeocystis sp. and chlorophyll a, expressed as the amount of chlorophyll a per cell 

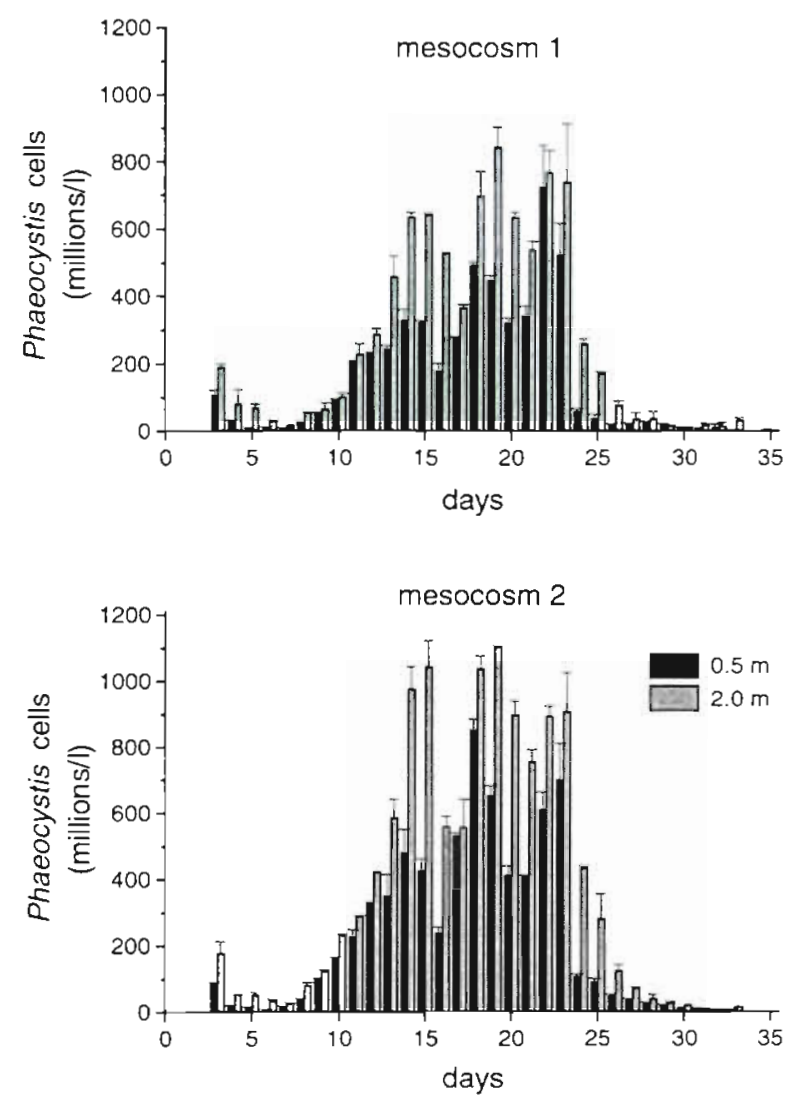

Fig. 4. Numbers of Phaeocystis cells measured in the daily removed sediment traps at $0.5 \mathrm{~m}$ depth (black columns) and $2.0 \mathrm{~m}$ depth (grey columns). Error bars indicate the standard deviation between the duplicate traps

Fig. 4. The pattern in Fig. 4 is rather similar to the development of Phaeocystis cells in the water column (Fig. 2), suggesting that sedimentation is directly related to the standing stock in the water column. In contrast to the cell numbers in the water column, a significant difference (paired $t$-test of the log of the ratio of 2.0 and $0.5 \mathrm{~m}, 2$ pairs, $\alpha=0.05$ ) was found between the upper and the lower sediment traps: at $2.0 \mathrm{~m}$ depth, the total amount of cells collected in the traps over $35 \mathrm{~d}$ was $70 \%$ higher than at $0.5 \mathrm{~m}$ depth. A similar situation was found for chlorophyll a (data not shown): although no depth gradient could be observed in the water column, a significant difference (paired $t$-test of the $\log$ of the ratio of 2.0 and $0.5 \mathrm{~m}, 2$ pairs, $\alpha=0.05$ ) was found in the sediment traps; the total amount of chlorophyll a collected over $35 \mathrm{~d}$ in the lower traps was also $70 \%$ higher than the amount collected in the upper traps.

This discrepancy between the 2 depths was reflected in the calculated sinking velocities for Phaeocystis cells (data not shown), which were in general higher at $2.0 \mathrm{~m}$. As an estimate of the average daily sinking
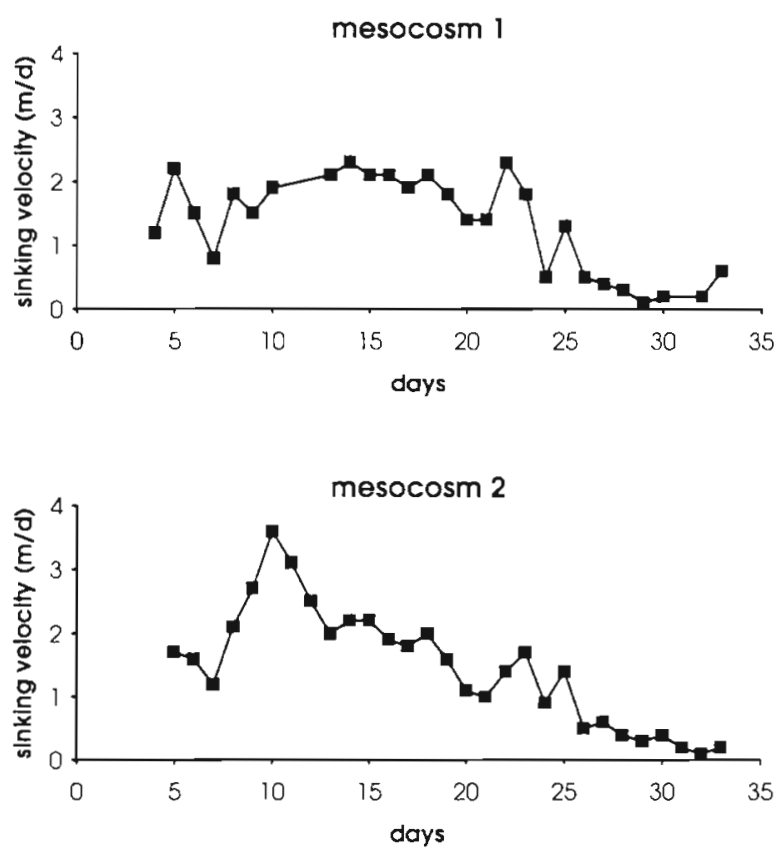

Fig. 5. Average daily sinking velocities $\left(\mathrm{m} \mathrm{d}^{-1}\right)$ of the Phaeocystis cells, calculated by averaging the values from 0.5 and $2.0 \mathrm{~m}$

velocities of Phaeocystis cells in the mesocosms, the daily averages of 0.5 and $2.0 \mathrm{~m}$ were calculated (Fig. 5). These average daily sinking velocities varied between 0.1 and $3.6 \mathrm{~m} \mathrm{~d}^{-1}$. The sinking velocity did not show spectacular fluctuations during the Phaeocystis bloom. It did not increase at the decline of the bloom, nor during periods of high DMS formation. The lowest sinking velocities were found at and after the decline of the bloom.

All calculated values together resulted in an average sinking velocity of $1.4 \mathrm{~m} \mathrm{~d}^{-1}$ for Phaeocystis $\mathrm{sp}$ in these mesocosms. This alone indicates that sedimentation must be quantitatively important in a $3.0 \mathrm{~m}$ mesocosm. To show this importance, the accumulation of deposited Phaeocystis sp, during the experiment is presented in relation to the development of the cell numbers in the water column (Fig. 6). Because of the differences found between 0.5 and $2.0 \mathrm{~m}$, the sedimentation rates in this figure were based on the results of the lower traps, since these are closer to the mesocosm floor and, hence, are more likely to reflect the situation there. Fig. 6 shows that the number of Phaeocystis cells on the mesocosm floor already exceeded the standing stock in the water column a few days after the start of the experiment. During the blooming period of Phaeocystis sp., the daily loss of cells due to sedimentation was nearly equal to the average standing stock in this period. 

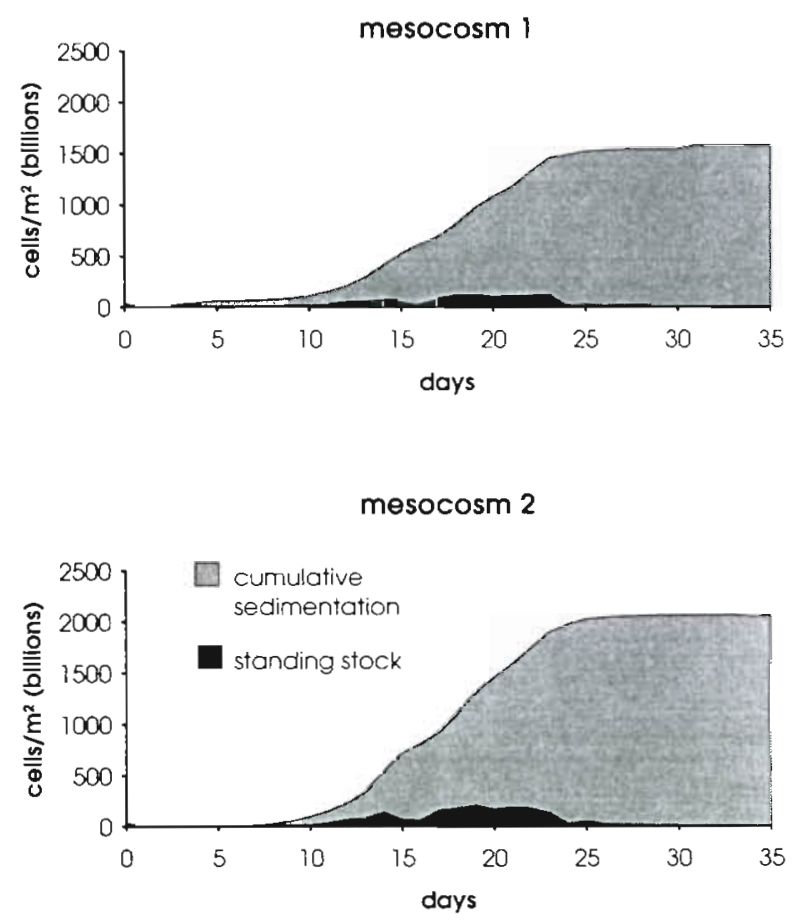

Fig. 6. Comparison of the amount of Phaeocystis cells on the mesocosm floor, calculated by addition of daily sedimentation (grey area), with the standing stock in the water column (black area)

Cumulative sedimentation of chlorophyll a at $2.0 \mathrm{~m}$ depth was compared to the chlorophyll a measurements in the smaller traps, expressed per square meter using Eq. (3) (Fig. 7). The measurements (represented by the black bars) were in good agreement with the calculated cumulative values, indicating that the degradation rate of chlorophyll a in these traps was low. However, microbial activity did take place in the traps: it was observed that most of the material collected in the traps was black, which indicates sulfide production by sulfate reducing bacteria.

The measurements of organic carbon and nitrogen in the smaller traps were also expressed per square meter. The amount of organic nitrogen on the floor of the mesocosms just after the decline of the Phaeocystis bloom (Day 25) was $5.05 \mathrm{gN} \mathrm{m}^{-2}$ (SD of mesocosms = $0.15)$. This amount is nearly equal to the measured amount of free inorganic nitrogen present in the water column before the bloom started (Day 7), which was $5.13 \mathrm{gN} \mathrm{m}^{-2}$ (SD of mesocosms $=0.01$ ).

In Table 1 , the results from the measurements at the mesocosm floor at the end of the experiment (Day 35) are compared to the measurements in the sediment trap that had been placed in Den Helder harbour. The sedimentation of chlorophyll $a$ in the harbour was comparable to the sedimentation of chlorophyll $a$ in the mesocosms. However, the amounts of organic carbon
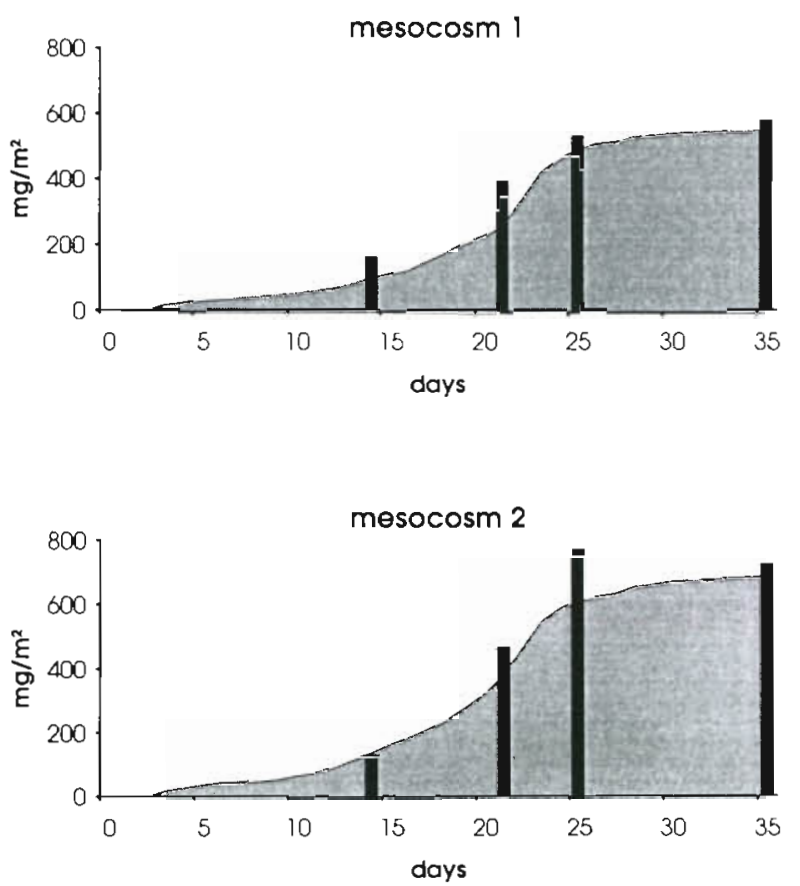

Fig. 7 Accumulation of daily sedimentation of chlorophyll a (grey area), compared to the actual amounts of chlorophyll a on the mesocosm floor, which were measured in the sediment traps at $3 \mathrm{~m}$ depth (black bars)

Table 1. Chlorophyll $a$, organic carbon and organic nitrogen in the trap from Den Helder harbour and in the traps at the mesocosm floor that were removed after $35 \mathrm{~d}$. SD of mesocosms given in parentheses

\begin{tabular}{|lcc|}
\hline & Mesocosms & Harbour \\
\hline Chlorophyll a $\left(\mathrm{mg} \mathrm{m}^{-2}\right)$ & $655(75)$ & 670 \\
Organic carbon $\left(\mathrm{gC} \mathrm{m}^{-2}\right)$ & $28.0(5.8)$ & 132.1 \\
Organic nitrogen $\left(\mathrm{gN} \mathrm{m}^{-2}\right)$ & $4.1(0.7)$ & 19.3 \\
\hline
\end{tabular}

and nitrogen in the harbour-trap were considerably higher, suggesting an additional input of refractory material into this trap.

Net production of Phaeocystis sp., estimated from the daily sedimentation using Eq. (5), is presented in Fig. 8. The peak values for DMS (Fig. 3) were not reflected in the pattern for net production. A negative net production was found on Day 24, at the decline of the bloom.

\section{HPLC measurements of acrylic acid and DMSP}

Under the given conditions, the retention time for acrylic acid in the HPLC was between 2.9 and $3.1 \mathrm{~min}$. The retention time depends on the methanol concen- 


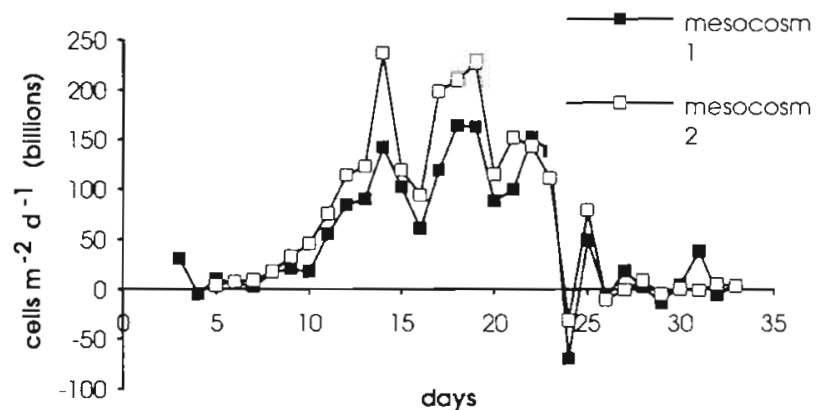

Fig. 8. Calculated rates of daily net production of Phaeocystis sp. during the experiment. Negative rates indicate a decrease in Phaeocystis biomass that cannot be explained by sedimentation only

tration in the carrier fluid: higher methanol concentrations decrease the retention time. The detection limit for this method is about $1 \mu \mathrm{M}$. The concentrations of dissolved acrylate and DMSP were below this detection limit, except for a few samples from the sediment traps.

The results of the HPLC measurements of particlebound acrylate and DMSP in the water column are shown in Fig. 9, in which the concentrations of both
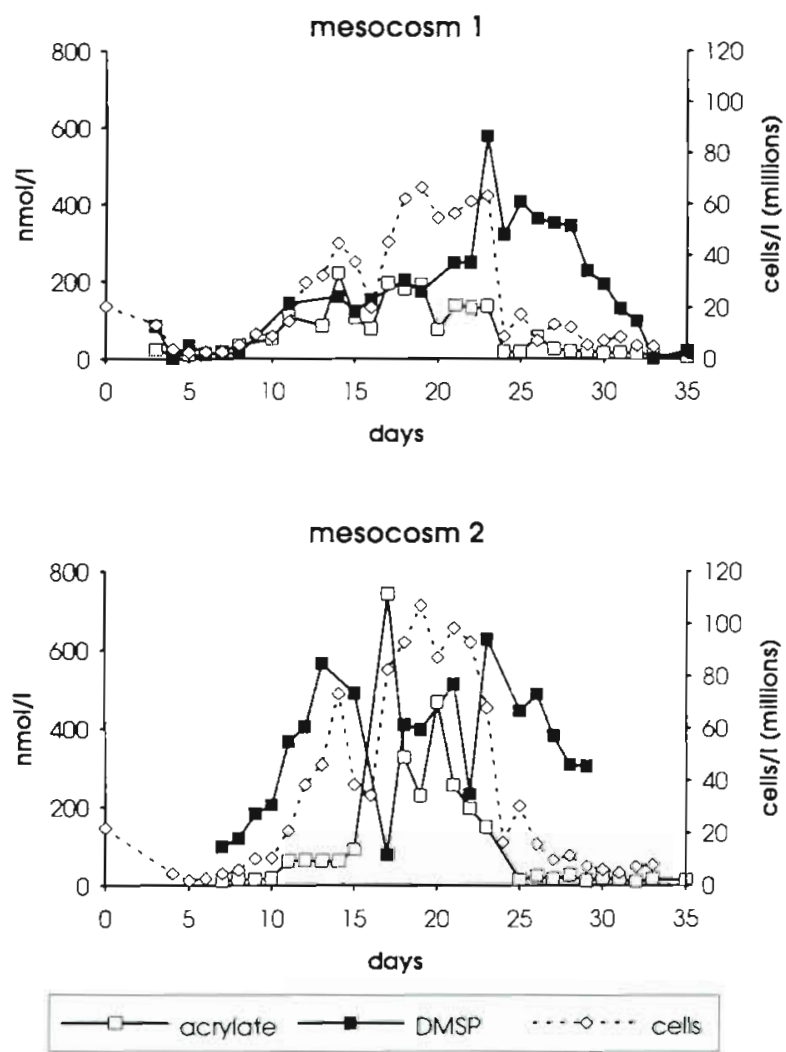

Fig. 9. Concentrations of particle-bound acrylate and DMSP in the water column (at $2.0 \mathrm{~m}$ depth) as measured by HPLC analysis. Phaeocystis cell numbers are also plotted

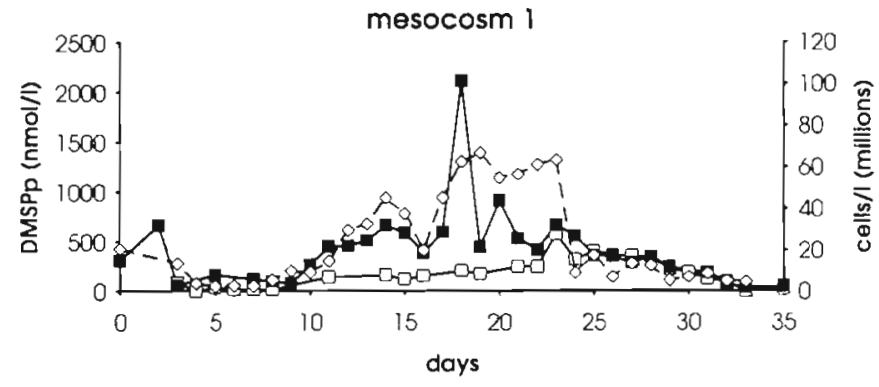

mesocosm 2

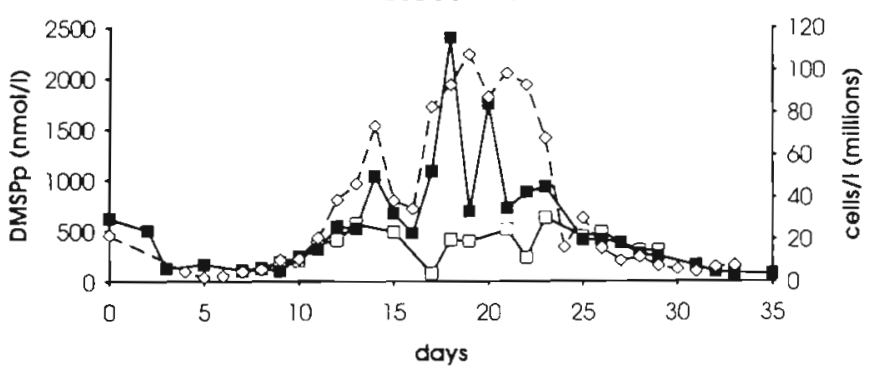

$\longrightarrow$ HPLC $\longrightarrow$ GC $\quad-\infty \cdots$ Phaeocystis

Fig. 1.0. Concentrations of particulate DMSP in the water column, calculated from both HPLC measurements of acrylate (measured at $2.0 \mathrm{~m}$ depth) and GC measurements of DMS. To show the relation with the occurrence of Phaeocystis sp. Phaeocystis cell numbers are plotted here as well

compounds are plotted together with the Phaeocystis cell numbers in the water column. Although elevated DMSP concentrations were found during the blooming period of Phaeocystis, the curves of DMSP and Phaeocystis cell numbers show different shapes: DMSP was also found in considerable amounts after the Phaeocystis bloom. In contrast, acrylate seemed to be produced mainly in the periods with high Phaeocystis cell numbers.

The results from the sediment traps (data not shown) were used to calculate the sinking velocities for DMSP (Eq. 2). This resulted in averages of $1.72 \mathrm{~m} \mathrm{~d}^{-1}$ and $1.76 \mathrm{~m} \mathrm{~d}^{-1}$ in Mesocosms 1 and 2 respectively, which is similar to the average sinking velocities for Phaeocystis cells calculated from the lower traps (Table 1).

Intercalibration of the HPLC measurements of particle-bound DMSP with the values measured by GC analysis resulted in Fig. 10. Both techniques yielded comparable results in the early phase and in the end phase of the experiment. In between these phases, a large discrepancy between the 2 methods occurred: the values measured by GC were considerably higher in this period, and showed much greater variation. This discrepancy coincided with the occurrence of high Phaeocystis cell numbers, which are also plotted in Fig. 10 
The GC measurements of DMSP showed a strong increase of particulate DMSP at Day 18 , followed by an equally strong decrease at Day 19. The same phenomena occurred at Days 20 and 21, although the differences in the concentration were not as high.

\section{DISCUSSION AND CONCLUSIONS}

\section{Methodological considerations}

The mesocosms are a useful tool for mimicking a phytoplankton bloom. Under the given experimental conditions, a bloom of Phaeocystis sp. was successfully simulated: the observed maximum cell numbers in the mesocosms were comparable to field measurements (Cadée \& Hegeman 1986, Van Boekel et al. 1992). The duplicate mesocosms gave comparable results: although the rates and concentrations were in general lower in Mesocosm 1, the observed patterns showed a remarkable similarity, indicating that the development in Mesocosm 1 was in phase with Mesocosm 2.

The method for measuring acrylate in sea water gives good results for concentrations higher than $1 \mu \mathrm{M}$. Acrylate concentrations in the field are expected to be much lower: if acrylate is produced from DMSP in a $1: 1$ ratio with DMS, the in situ concentration will be in the same order of magnitude as the DMS concentration, which is generally far below $1 \mu \mathrm{M}$ (Cooper \& Matrai 1989). The technique is therefore not suitable for measuring dissolved acrylate and DMSP, since these have to be detected directly in a sea water sample. Our measurements of the dissolved fraction in the mesocosms confirm this conclusion. The technique can however be useful to measure particle-bound acrylate and DMSP, which are easily preconcentrated on a filter.

Although it is not as sensitive as GC measurements of DMSP via DMS, the HPLC method has the advantage that it is less time-consuming. This makes it a reasonable alternative for GC analysis, for instance, for work with algal cultures in which DMSP concentrations are high. The HPLC measurements were in good agreement with the GC measurements as long as Phaeocystis sp. was not dominant. The observed discrepancy with GC measurements in the mid phase of the experiment may have been caused by the DMSP lyases of Phaeocystis sp. Disruption of cells during filtration could have brought the intracellular DMSP into contact with these enzymes, leading to a rapid cleavage reaction before the filters were heated. In fact, DMS was often smelled during filtration, which supports this idea of rapid cleavage. This cleavage will lead to an underestimation of the DMSP concentration, and may explain the observed correlation between acrylate concentrations and Phaeocystis cell numbers.
Although the results suggest a major role for the lyases of Phaeocystis sp., bacterial DMSP-lyase activity has also been demonstrated to be a rapid process (De Souza \& Yoch 1995). Therefore, a technique to block the enzyme activity immediately after sampling has to be developed to improve the HPLC method. Hence, our HPLC results have to be interpreted with care.

There was another unexplained feature in our results: the homogenous distribution of chlorophyll a and Phaeocystis cells in the water column was not reflected in the amounts collected in the sediment traps, which were significantly higher at $2.0 \mathrm{~m}$ depth. According to Eq. (1), this can only be caused by an increase of the sinking velocity at greater depth. Aggregation processes can increase the sinking velocity of Phaeocystis colonies (Wassmann 1994), but it is unclear which role these processes play in a $3.0 \mathrm{~m}$ mesocosm. In addition, the material in the $2.0 \mathrm{~m}$ sediment traps was visually not different from the material in the $0.5 \mathrm{~m}$ traps.

In a sheltered system, it is likely that the standing stock increases with depth: sinking cells will increase the biomass in lower layers, thus increasing the production potential of these layers. If this is true, the standing stock at both depths has not been determined accurately, since no concentration gradient was found. A likely cause for a disturbance of such a concentration gradient is the sampling procedure: if a concentration gradient existed in the water column, it may have been disturbed by the daily removal of the sediment traps, which took always place shortly before the samples from the water column were taken, or by the water sampler itself. Obviously, this has implications for the calculated sinking velocities at $0.5 \mathrm{~m}$, which will have been underestimated, and at $2.0 \mathrm{~m}$, which will have been overestimated. Hence, the average of these 2 depths seems to be the best estimate of the real average sinking velocities in the mesocosms.

\section{Phytoplankton dynamics, DMS and DMSP}

The amounts of chlorophyll a collected after $35 \mathrm{~d}$ in sediment traps inside and outside the mesocosms were in the same range, indicating that the mesocosm reasonably reflected the algal production in the Marsdiep area, despite the addition of extra nutrients. The much higher amounts of organic carbon and nitrogen collected in the trap outside the mesocosm can be explained by a continuous input of detritus, which probably resuspends from the sea floor due to tidal currents.

Comparison of the cumulative daily sedimentation with the actual amount of chlorophyll $a$ at the mesocosm floor at Day 35 showed that the degradation of 
chlorophyll a was very low compared to the production. This may be caused by oxygen depletion in the sediment traps: chlorophyll a is much more persistent under anoxic conditions than under oxic conditions (Sun et al. 1993). The observed sulfate reduction activity confirms that anoxia occurred inside the traps. When this low degradation of chlorophyll a is taken into account, the agreement between cumulative daily sedimentation and the content of the traps at the mesocosm floor shows that the simple sediment trap technique that we used here yields reasonably consistent results

Since organic carbon and nitrogen were not measured in the water column, it is difficult to estimate mineralization rates for these compounds. It is however clear that there is a considerable flux of organic nitrogen to the mesocosm floor. The mesocosm floor will thus play an important role in the nitrogen cycle in these sytems.

To estimate the relative dominance of Phaeocystis sp. in these experiments, we compared the calculated amounts of chlorophyll a per Phaeocystis cell in the mesocosms with values measured in Phaeocystis cells isolated from the southern North Sea, which varied between 0.13 and $0.60 \mathrm{pg}$ cell $^{-1}$ (Buma et al. 1991, Lancelot et al. 1991). The values measured during the Phaeocystis bloom in the mesocosms were close to the bottom end of this range, suggesting that the phytoplankton population in this period was almost a monoculture of Phaeocystis. The high chlorophyll a contents measured before and after the Phaeocystis bloom indicate the presence of other species, which was confirmed by microscopic observations of Quist et al. (in press), who found that the diatom Nitzschia closterium in particular was present in significant amounts during these periods.

The importance of sedimentation for Phaeocystis in this experiment is evident, but this is mainly due to the experimental circumstances. The average sinking velocity of $1.4 \mathrm{~m} \mathrm{~d}^{-1}$ indicates that daily losses due to sedimentation in the southern North Sea will be much smaller than in these mesocosms, since the southern North Sea is much deeper and much more turbulent. The value of $1.4 \mathrm{~m} \mathrm{~d}^{-1}$ is low compared to the value of $6 \mathrm{~m} \mathrm{~d}^{-1}$ that was reported for Phaeocystis colonies in the Marsdiep area (Van Boekel et al. 1992). This may be explained by the continuous presence of many non-colonial cells, which have a much lower sinking velocity.

According to Riegman et al. (1992), blooms of colonial Phaeocystis sp. mainly occur in areas characterized by a high nitrate availabijty. The low nitrate concentration in the mesocosms at Day 24 therefore indicates that the Phaeocystis bloom in the mesocosms mav have declined due to nitrate-Iimitation. This nutri- ent stress did not lead to an increased sinking velocity of Phaeocystis sp. Only $50 \%$ of the observed loss of biomass during the decline of the bloom could be attributed to sedimentation, which explains the negatjve net production at Day 24. Mass cell. lysis will probably have occurred in the water column on this day. This suggests that lysis in the water column due to nutrient stress is the main process terminating the Phaeocystis bloom, which is in agreement with the conclusions of Van Boekel et al. (1992).

Since sedimentation was not measured on the first $2 \mathrm{~d}$, it is not possible to say which process caused the observed decline of the phytoplankton population that was present in the Marsdiep water with which the mesocosms were filled. However, before the mesocosms were filled, this water had been stored for $2 \mathrm{~d}$ in a dark container. This may have had a negative effect on the algae.

If we assume that the underestimation of the DMSP concentrations measured by HPLC due to enzyme activity is the same in samples from the water column and the sediment traps, the calculated average sinking velocity for DMSP will be reasonably accurate. Since this velocity was similar to the average sinking velocity of the Phaeocystis cells, it may be assumed that freshly deposited Phaeocystis cells still contained most of their intracellular DMSP. The daily loss of Phaeocystis cells due to sedimentation was considerable and constantly related to standing stock in the water column. Hence, the daily flux of DMSP to the mesocosm floor must have been continuously high during the blooming period of this species. As a consequence, release of DMSP and formation of DMS is likely to have occurred to a large extent on the mesocosm floor.

It should be noted here again that in the southern North Sea, sedimentation will have less impact than in the mesocosms. Therefore, it cannot be concluded that the mechanism of DMS production after sedimentation is important in the southern North Sea. Nevertheless, deposition of DMSP due to sedimentation of intact cells may be significant in areas characterised by low turbulence and shallow depths, e.g. in certain areas in the Dutch Wadden Sea. Deposition of DMSP-containing algae seems to occur in stratified areas as well. Nedwell et al. (1994) reported on very high DMSP and DMS concentrations in and above sediments in the northern North Sea.

In the mesocosms, the continuously high sedimentation of Phaeocystis sp. and DMSP did not lead to continously high DMS concentrations in the water column. This points to other factors involved in the regulation of the DMS concentration. Microbial activity may be important in this regard. Kiene \& Bates (1990) reported a high bacterial. tumover rate for Lvis. In addition, Kiene \& Service (1991) found that less than $30 \%$ of the 
DMSP produced in estuarine waters was converted to DMS. Hence, the DMS concentration in sea water will usually be much lower than the concentration of particulate DMSP. However, when this close coupling between DMSP production and microbial consumption of DMSP and DMS is disturbed for whatever reason, accumulation of DMS may occur. Such an accumulation took place during the first days of our experiment, when the concentration DMS was rather high relative to the amount of particulate DMSP. The decline of the phytoplankton population present in the initial water may have caused a sudden increase in the concentration of dissolved DMSP followed by rapid cleavage of DMSP by the DMSP lyases, which may still have been present in the decaying algae. The growth of the DMS(P) consuming bacteria may not have equalled this rapid production of dissolved DMSP and DMS. Low microbial consumption rates of DMSP and DMS may thus have enabled these relatively high concentrations of DMS. More details on the role of bacteria in this experiment will be presented by Quist et al. (in press)

Regarding the dominance of Phaeocystis sp. around Day 19, the second DMS peak must have originated from DMSP production by this species. This peak did not occur at the decline of the Phaeocystis bloom, as was predicted by Liss et al. (1994), but during the late exponential growth phase of the bloom. The mass lysis that probably occurred at the decline of the bloom did apparently not lead to elevated. DMS concentrations.

The hypothesis that the DMS peak was caused by a mass sedimentation event can be rejected, since the peak was not preceded by an increased sinking rate of Phaeocystis sp. It was therefore concluded that enhanced production of DMSP by the algae must have caused the DMS peak. Phaeocystis may increase its DMSP production under nitrogen limitation: DMSP can be used for osmoregulation (Dickson \& Kirst 1987), and under nitrogen limitation, production of DMSP may replace the production of other osmolytes that contain nitrogen (Turner et al. 1988). The steep peak in the concentration of particulate DMSP observed on Day 18 indeed suggests elevated DMSP production, which was however followed by a strong release of DMSP on Day 19. The latter does not support the osmolyte theory, since no sudden changes in salinity occurred in this phase of the experiment (data not shown).

Since DMSP-lyase activity was assumed to be responsible for the production of acrylate in the HPLC samples, the amount of acrylate measured may give a rough indication of the activity of these enzymes. The highest values were observed during the exponential growth phase of Phaeocystis sp., implying that the capacity to split DMSP is already maximal before the enhanced production of DMSP takes place. A possible function of this early enzyme activity is that the production of acrylate from DMSP may inhibit grazing by zooplankton. Estep et al. (1990) compared consumption of acrylate by zooplankton with eating hot plastic. These authors reported the observation that the copepod Calanus finmarchicus rejected colonies of Phaeocystis pouchetii immediately after ingestion. This may have been caused either by high concentrations of acrylate inside the colonies or by release of DMSP by the cells during grazing, followed by a rapid enzymatic production of acrylate.

However, the anti-grazing properties of acrylate can not explain the mass release of DMSP at Day 19 , although a possible relation with zooplankton grazing is suggested by Quist et al. (in press). Hence, for a better understanding of the relation between Phaeocystis sp. and DMS, future research should focus on the possible functions of DMSP production by Phaeocystis sp., and on the specific environmental conditions en-hancing this production.

Acknowledgements. The authors thank Rikus Kloosterhuis for his assistance with CHN analysis. Fruitful discussions with Herman Ridderinkhof and Geert-Jan Brummer led to a better interpretation of the results from the sediment traps. This study was funded by the Dutch National Research Programm (project NOLK/026/90). NIOZ publication number 3017

\section{LITERATURE CITED}

Andreae MO (1990) Ocean-atmosphere interactions in the global biogeochemical sulfur cycle. Mar Chem 30:1-29

Barnard WR, Andreae MO, Iverson RL (1984) Dimethylsulfide and Phaeocystis pouchetii in the southeastern Bering Sea. Cont Shelf Res 3:103-113

Baumann MEM, Lancelot C, Brandini FP, Sakshaug E, John DM (1994) The taxonomic identity of the cosmopolitan prymnesiophyte Phaeocystis, a morphological and ecophysiological approach. J mar Syst 5:5-22

Belviso S. Corn M, Buat-Menard P (1993) Assessment of the role of zooplankton in the cycling of DMSP and DMS in the water column during EUMELI-4 (France-JGOFS). In: Restelli G. Angeletti G (eds) Dimethylsulfide, oceans, atmosphere and climate. Kluwer Academic Publishers, Dordrecht, p 15-19

Brimblecombe P, Shooter D (1986) Photo-oxidation of dimethylsulfide in aqueous solution. Mar Chem 19: 343-353

Buma AGJ, Bano N, Veldhuis MJW, Kraay GW (1991) Comparison of the pigmentation of two strains of the prymnesiophyte Phaeocystis sp. Neth J Sea Res 27:173-182

Cadée GC, Hegeman J (1986) Seasonal and annual variation in Phaeocystis pouchetii (Haptophyceae) in the westernmost inlet of the Wadden Sea during the 1973 to 1985 period. Neth J Sea Res 20:29-36

Charlson RJ, Lovelock JE, Andreae MO, Warren SG (1987) Oceanic phytoplankton, atmospheric sulfur, cloud albedo and climate. Nature 326:65.5-661

Cooper WJ, Matrai PA (1989) Distribution of dimethylsulfide 
in the oceans: review. In: Saltzman ES, Cooper WJ (eds) Biogenic sulfur in the environment. American Chemical Society Symp Ser 393, Washington, DC, p 140-151

Dacey JWH, Blough NV (1987) Hydroxıde decomposition of dimethylsulfoniopropionate to form dimethylsulfide. Geophys Res Lett 14:1246-1249

Dacey JWH, Wakeham SG (1986) Oceanic dimethylsulfide: production during zooplankton grazing on phytoplankton. Science 233:1314-1316

De Souza MP, Yoch DC (1995) Purification and characterization of dimethylsulfoniopropionate lyase from an Alcaligenes-like dimethylsulfide-producing marine isolate. Appl environ Microbiol 61:21-26

Dickson DMJ, Kirst GO (1987) Osmotic adjustment in marine eukaryotic algae: the role of inorganic ions, quaternary ammonium, tertiary sulphonium and carbohydrate solutes. II. Prasinophytes and haptophytes. New Phytol 106:657-666

Estep KW. Nejstgaard JCh, Skjoldal HR, Rey F (1990) Predation by copepods upon natural populations of Phaeocystis pouchetii as a function of the physiological state of the prey. Mar Ecol Prog Ser 67:235-249

Gibson JAE, Garrick RC, Burton HR, McTaggart AR (1990) Dimethylsulfide and the alga Phaeocystis pouchetii in Antarctic coastal waters. Mar Biol 104:339-346

Holligan PM, Turner SM, Liss PS (1987) Measurements of dimethyl sulphide in frontal regions. Cont Shelf Res 7 : $213-224$

Iverson RL, Nearhoof FL, Andreae MO (1989) Production of dimethylsulfonium propionate and dimethylsulfide by phytoplankton in estuarine and coastal waters. Limnol Oceanogr 34:53-67

Keller MD, Bellows WK, Guillard RRL (1989) Dimethylsulfide production in marine phytoplankton. In: Saltzman ES, Cooper WJ (eds) Biogenic sulfur in the environment. American Chemical Society Symp Ser 393, Washington DC, p 140-151

Kiene RP, Bates TS (1990) Biological removal of dimethyl sulphide from seawater. Nature 345:702-705

Kiene RP, Service SK (1991) Decomposition of dissolved DMSP and DMS in estuarine waters: dependence on temperature and substrate concentration. Mar Ecol Prog Ser 76:1-11

Kiene RP, Taylor BF (1988) Demethylation of dimethylsulfoniopropionate and production of thiols in anoxic marine sediments. Appl environ Microbiol 54:2208-2212

Kwint RLJ, Kramer KJM (1995) DMS production by plankton communities. Mar Ecol Prog Ser 121:227-237

Kwint RLJ, Kramer KJM, Baart AC, Verhacen HLM (1993) The production of DMS by a plankton community: a mesocosm experiment. In: Restelli G, Angeletti $G$ (eds) Dimethylsulfide, oceans, atmosphere and climate. Kluwer Academic Publishers, Dordrecht, p 53-62

Lancelot C, Billen G, Barth H (1991) The dynamics of Phaeocystis blooms in nutrient enriched coastal zones. Water Pollut Res Rep 23, E Guyot, Brussels

Lawrence MG (1993) An empirical analysis of the strength of the phytoplankton-dimethylsulfide-cloud-climate feed back cycle. J geophys Res 98:20663-20673

Lindqvist F (1989) Sulphur-specific detection in air by photo-

This article was submitted to the editor ionization in a multiple detector gas chromatography sys tem. J High Resolut Chromatogr 12:628-631

Liss PS, Malin G, Turner SM, Holligan PM (1994) Dimethyl sulphide and Phaeocystis: a review. J mar Syst 5:41-53

Matrai PA, Keller MD (1994) Tolal organic sulfur and dimethylsulfoniopropionate in marine phytoplankton: intracellular variations. Mar Biol 119:61-68

Nedwell DB, Shabbeer MT, Harrison RM (1994) Dimethylsulfide in North Sea waters and sediments. Estuar coast Shelf Sci 39:209-217

Olesen $M$ (1993) The fate of an early diatom spring bloom. Ophelia 37:51-56

Osinga $\mathrm{R}$, Lewis WE, Wopereis JLM, Vriezen CJA, Van Duyl FC (1995) Effects of the sea urchin Echinocardium cordatum on mineralization rates in experimental benthic systems under increasing organic loading. Ophelia 41 221-236

Parsons RT, Maita Y, Lalli CM (1984) A manual of chemical and biological methods for seawater analysis. Pergamon Press, Oxford $p 173$

Quist P, Kwint RLJ, Hansen TA, Dijkhuisen L, Kramer KJM (in press) Turnover of dimethlylsulfoniopropionate and dimethylsulfide in the marine environment-a mesocosm experiment. Mar Ecol Prog Ser

Riebesell U (1989) Comparison of sinking and sedimentation rate measurements in a diatom winter/spring bloom. Mar Ecol Prog Ser 54:109-119

Riebesell U (1993) Aggregation of Phaeocystis during phytoplankton spring blooms in the southern North Sea. Mar Ecol Prog Ser 96:281-289

Riegman R, Noordeloos AAM, Cadée GC (1992) Phaeocystis blooms and eutrophication of the continental coastal zones of the North Sea. Mar Biol 112:479-484

Stefels J, Van Boekel WHM (1993) Production of DMS from dissolved DMSP in axenic cultures of the marine phytoplankton species Phaeocystis sp. Mar Ecol Prog Ser 97: $11-18$

Sun MY, Lee C, Aller RC (1993) Laboratory studies of oxic and anoxic degradation of chlorophyll-a in Long Island Sound sediments. Geochim cosmochim Acta 57:147-157

Turner SM, Malin G, Liss PS, Harbour DS, Holligan PM, (1988) The seasonal variation of dimethyl sulphide and dimethylsulfoniopropionate concentrations in nearshore waters. Limnol Oceanogr 33:364-375

Van Boekel WHM, Hansen FC, Riegman R, Bak RPM (1992) Lysis induced decline of a Phacocystis spring bloom and coupling with the microbial food web. Mar Ecol Prog Ser 81:269-276

Van Duyl FC, Kop AJ, Kok A, Sandee AJJ (1992) The impact of organic matter and macrozoobenthos on bacterial and oxygen variables in marine sediment boxcosms. Neth $\mathrm{J}$ Sea Res 29:343-355

Verardo DJ, Froelich PN, McIntyre A (1990) Determination of organic carbon and nitrogen in sediments using the Carlo Erba Na-1500 analyzer. Deep Sea Res 37:157-165

Wassmann P (1994) Significance of sedimentation for the termination of Phaeocystis blooms. J mar Syst 5:81-100

Wassmann P, Vernet M, Mitchell BG, Rey F (1990) Mass sedimentation of Phaeocystis pouchetii in the Barents Sea. Mar Ecol Prog Ser 66:183-195

Manuscript first received: December 28, 1994

Revised version accepted: August 11, 1995 